\title{
Involvement of tumor acidification in brain cancer pathophysiology
}

\author{
Avinash Honasoge and Harald Sontheimer* \\ Department of Neurobiology and Center for Glial Biology in Medicine, University of Alabama at Birmingham, Birmingham, AL, USA
}

\section{Edited by:}

Ebbe Boedtkjer, Aarhus University,

Denmark

\section{Reviewed by:}

Pawel Swietach, Oxford University, UK

Stephan J. Reshkin, University of Bari, Italy

Albrecht Schwab, Westfälische

Wilhelms-Universität Münster,

Germany

\section{${ }^{*}$ Correspondence}

Harald Sontheimer, Department of Neurobiology, University of Alabama

at Birmingham, 1719 6th Ave.

South, CIRC 410, Birmingham AL

35294, USA

e-mail: sontheimer@uab.edu
Gliomas, primary brain cancers, are characterized by remarkable invasiveness and fast growth. While they share many qualities with other solid tumors, gliomas have developed special mechanisms to convert the cramped brain space and other limitations afforded by the privileged central nervous system into pathophysiological advantages. In this review we discuss gliomas and other primary brain cancers in the context of acid-base regulation and interstitial acidification; namely, how the altered proton $\left(\mathrm{H}^{+}\right)$content surrounding these brain tumors influences tumor development in both autocrine and paracrine manners. As proton movement is directly coupled to movement of other ions, $\mathrm{pH}$ serves as both a regulator of cell activity as well as an indirect readout of other cellular functions. In the case of brain tumors, these processes result in pathophysiology unique to the central nervous system. We will highlight what is known about $\mathrm{pH}$-sensitive processes in brain tumors in addition to gleaning insight from other solid tumors.

Keywords: glioma, pH, NHE, brain cancer, solid tumor, acidification
Primary brain tumors stand out amongst solid tumors in both their location and their pathophysiology. The most common and aggressive type of primary brain tumors, glioma, invades brain space while simultaneously destroying surrounding tissue in an attempt to increase brain real estate (Watkins and Sontheimer, 2012). As with other solid tumors, gliomas display enhanced glycolysis and heightened acidification of the tissue interstitium (Vlashi et al., 2011). Unlike other solid tumors, however, gliomas face both brain-specific cellular interactions (Charles et al., 2011) and chemical composition (Irani, 2008). This results in unique pathophysiological consequences. In this review, we will highlight the mechanisms by which brain tumors regulate both their intracellular $\mathrm{pH}\left(\mathrm{pH}_{\mathrm{i}}\right)$ and also the $\mathrm{pH}$ of the surrounding tissue $\left(\mathrm{pH}_{\mathrm{e}}\right)$, and how this $\mathrm{pH}$ regulation affects tumor pathogenicity.

\section{$\mathrm{pH}_{\mathrm{i}}$ REGULATION}

Tumor cells constantly struggle to resist the electrochemical gradients of protons, weak acids, and weak bases generally acidifying the cell (Webb et al., 2011; Bevensee and Boron, 2013). Thus a major driving force in understanding tumor acid-base physiology is understanding the transport of protons across the plasma membrane. This transport uses either energy substrates or is coupled to the electrochemically-favorable transport of a second molecule. The following section explains the roles of various $\mathrm{H}^{+}$-coupled transporters and exchangers in brain tumor $\mathrm{pH}_{\mathrm{i}}$ regulation (Figure 1).

Most initial studies on glioma cell $\mathrm{pH}_{\mathrm{i}}$ regulation used $\mathrm{C} 6$ rat glioma cells, which were generated by exposure to $N, N^{\prime}$ nitroso-methylurea and used throughout the 1980s and 1990s as a convenient cell line for studying astrocytic physiology including cytotoxic edema, cerebral ischemia, and volume regulation under osmotic challenge. For a thorough review of the C6 line, please refer to Grobben et al. (2002). These studies often used changes in $\mathrm{pH}_{\mathrm{i}}$ as a proxy for transport of other ions such as $\mathrm{Na}^{+}, \mathrm{K}^{+}$, and $\mathrm{Cl}^{-}$. Only recently did the focus of inquiry shift to human glioma. With this caveat in mind, we will review some older literature that describes $\mathrm{pH}$ regulatory systems in $\mathrm{C} 6$ followed by newer literature on the biological targets of $\mathrm{pH}$ changes in human gliomas.

\section{$\mathrm{Na}^{+} / \mathrm{H}^{+}$EXCHANGE}

$\mathrm{Na}^{+} / \mathrm{H}^{+}$exchange (NHE) was originally identified in mouse muscle fibers (Aickin and Thomas, 1977) where it was shown to be the major regulator of $\mathrm{pH}_{\mathrm{i}}$. Owing to a strong inwardlydirected electrochemical gradient for $\mathrm{Na}^{+}$, it is ideally suited for proton extrusion, thereby alkalinizing $\mathrm{pH}_{\mathrm{i}}$ while simultaneously acidifying the interstitium (Figure 1). The first implications of NHE in glioma cells came from studies in C6 rat glioma cells and neuroblastoma $\mathrm{x}$ glioma hybrid cells (NG108-15), both used as model systems investigating NHE in adrenergic signaling (Hertel and Staehelin, 1983; Isom et al., 1987a; Nunnari et al., 1987). Later studies involved NHE in a wide variety of signaling pathways (Isom et al., 1987b; Neve et al., 1992). C6 glioma cells were also considered a viable model of glial cells during acidosis and postischemic brain edema, where $\mathrm{pH}_{\mathrm{i}}$ served as a secondary readout for NHE involvement in osmotic swelling and regulatory volume increase (Jakubovicz et al., 1987; Kempski et al., 1988; Jakubovicz and Klip, 1989; Staub et al., 1994) under mildly acidotic conditions $\left(\mathrm{pH}_{\mathrm{e}} 6.0-7.0\right)$. Later, it was postulated that NHE served to maintain homeostatic $\mathrm{pH}_{\mathrm{i}}$ at the cost of cell swelling (Kempski et al., 1990; Staub et al., 1990). This exchange was temperaturedependent, with increased activity at higher temperatures (Lui et al., 1995; Mountian et al., 1996). While these studies sought to implicate glial cells in cytotoxic edema, they also hinted at a robust 


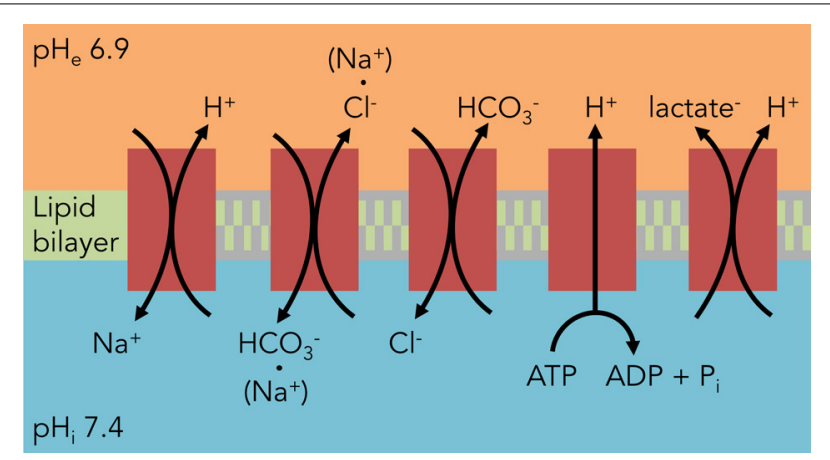

FIGURE 1 | Major components of $\mathbf{p H}_{\mathbf{i}}$ regulation in glioma cells. Unlike astrocytes, glioma cells rely heavily on $\mathrm{HCO}_{3}^{-}$-independent mechanisms to regulate their $\mathrm{pH}_{\mathrm{i}}$. The predominant acid extruder is $\mathrm{NHE} 1$, a Na+ $/ \mathrm{H}^{+}$ exchanger. All of these components except for the $\mathrm{H}^{+} \mathrm{V}$-ATPase also contribute to $\mathrm{C} 6$ glioma osmotic regulation from the transport of the counter-ion.

NHE mechanism that would soon be implicated as a hallmark of brain tumors.

The initial reports of NHE in brain tumor cell activity came from C6 glioma spheroids, where $\mathrm{H}^{+}$production under high glucose conditions was diminished by amiloride (Acker et al., 1992). Subsequently, Shrode et al. characterized differences in $\mathrm{pH}_{\mathrm{i}}$ regulation between $\mathrm{C} 6$ glioma cells and astrocytes, with the largest being a lack of $\mathrm{Na}^{+} / \mathrm{HCO}_{3}^{-}$transport in glioma cells (Shrode and Putnam, 1994). McLean et al. were the first to look at various human glioma cell lines and noted a significant elevation in $\mathrm{Na}^{+} / \mathrm{H}^{+}$exchanger subtype 1 (NHE1) expression, an increase in baseline $\mathrm{pH}_{\mathrm{i}}$, and an increased reliance on $\mathrm{HCO}_{3}^{-}$independent pathways versus primary rat astrocytes (McLean et al., 2000). As the NHE1 blocker amiloride is nonspecific and has off-target effects on glioma cells (Hegde et al., 2004), specific blockade of NHE1 with HOE642 (cariporide) confirmed a tonic activity for the $\mathrm{NHE} 1$ exchanger in glioma cell $\mathrm{pH}_{\mathrm{i}}$ regulation (Glunde et al., 2002). Interestingly, DNA hypermethylation decreases NHE1 expression in oligodendroglioma versus highergrade gliomas, potentially limiting the growth potential of these lower-grade gliomas (Blough et al., 2012). However, there have not been comprehensive studies of NHE subtypes in gliomas, with one study finding absence of NHE2 and NHE3 expression in C6 glioma cells (Willoughby et al., 2005). More recent studies have hinted at changes in $\mathrm{Na}^{+} / \mathrm{H}^{+}$exchanger recruitment to the cell surface (Kislin et al., 2009) and spatial organization within the tumor (Grillon et al., 2011).

\section{$\mathrm{Cl}^{-} / \mathrm{HCO}_{3}^{-}$EXCHANGE}

C6 glioma cells express both $\mathrm{Na}^{+}$-dependent and $\mathrm{Na}^{+}$independent modes of $\mathrm{Cl}^{-} / \mathrm{HCO}_{3}^{-}$exchange (Figure 1). The $\mathrm{Na}^{+}$-dependent transport is alkalinizing, while the $\mathrm{Na}^{+}$independent transport is acidifying in response to an intracellular alkalinization (Shrode and Putnam, 1994); these are blocked by the inhibitors $4,4^{\prime}$-diisothiocyano-2,2' -stilbenedisulfonic acid (DIDS) and 4-acetamido-4-isothiocyanatostilbene-2,2-disulfonic acid (SITS) (Kempski et al., 1988; Shrode and Putnam, 1994; Mountian et al., 1996; McLean et al., 2000). $\mathrm{Cl}^{-} / \mathrm{HCO}_{3}^{-}$ antiporter activity helps import $\mathrm{Cl}^{-}$ions in tandem with $\mathrm{Na}^{+}$ ions from the NHE to serve as osmotic agents for cell swelling in the face of acidosis (Staub et al., 1990; Mountian et al., 1996). The extrusion of $\mathrm{HCO}_{3}^{-}$seems to additionally act as a buffer for lactic acid (Staub et al., 1990), a finding discovered while investigating cerebral ischemia but that extrapolates well to the tumor microenvironment. Unlike non-transformed astrocytes, however, it appears glioma cells strongly lean on $\mathrm{CO}_{2} / \mathrm{HCO}_{3}^{-}$-independent mechanisms of acid extrusion (McLean et al., 2000).

\section{$\mathrm{H}^{+}$-LACTATE COTRANSPORT}

Proton-coupled lactate transporters help rid the cell of both acid and lactate loads simultaneously and thus play vital roles in tumor cellular metabolism and osmoregulation (Figure 1). Lactate efflux was first reported in C6 glioma cells to be a $\mathrm{pH}$ dependent phenomenon, with increased efflux at alkaline $\mathrm{pH}_{\mathrm{e}}$ (Lust et al., 1975). This transport was reversed in an astrocytoma cell line when the extracellular lactate and proton concentrations were increased (Lomneth et al., 1990; Tomsig et al., 1991), and lactate uptake in glioma cells was saturable at lower concentrations of lactate, indicating a carrier-dependent process (Dringen et al., 1995). This transport can be inhibited by the lactate transport inhibitors quercetin and alpha-cyano-4-hydroxycinnamate (CHC), which when used on $\mathrm{C} 6$ glioma cells prevented $\mathrm{H}^{+}$lactate efflux and decreased $\mathrm{pH}_{\mathrm{i}}$ (Volk et al., 1997). More recently, identification of two specific lactate transporters, MCT1 (Froberg et al., 2001; Mac and Nalecz, 2003; Grillon et al., 2011; MirandaGoncalves et al., 2013) and MCT4 (Grillon et al., 2011; MirandaGoncalves et al., 2013) in various types of brain tumors has provided molecular targets for disrupting brain tumor metabolism and $\mathrm{pH}_{\mathrm{i}}$ regulation.

\section{VACUOLAR-TYPE $\mathrm{H}^{+}$-ATPase}

Despite predominantly functioning as organellar proton pumps, there is evidence that V-ATPases translocate to the plasma membrane and regulate $\mathrm{pH}_{\mathrm{i}}$ in brain tumors (Figure 1). V-ATPase inhibitors such as bafilomycin A1 depolarized the membranes of NG108-15 neuroblastoma $\times$ glioma hybrid cells (Gerard et al., 1994, 1998) and C6 glioma cells (Philippe et al., 2002). Additionally, this V-ATPase was tonically active and alkalinized C6 glioma cells at physiological $\mathrm{pH}_{\mathrm{i}}$ (Volk et al., 1998). It should be noted, however, that plasma membrane expression of this proton pump is not limited to gliomas but also occurs in nontransformed astrocytes (Philippe et al., 2002). A more recent study has isolated the a4 isoform of the V0 subunit in human glioma samples, a subunit usually absent in normal human brain that is expressed in the kidney and epididymis (Gleize et al., 2012).

\section{AQUAPORINS AND CARBONIC ANHYDRASES}

Both of these protein types serve to facilitate a more rapid regulation of $\mathrm{pH}_{\mathrm{i}}$. Carbonic anhydrases do so by catalyzing the reversible interconversion of $\mathrm{CO}_{2}+\mathrm{H}_{2} \mathrm{O}$ and $\mathrm{HCO}_{3}^{-}+\mathrm{H}^{+}$, while aquaporins may be involved in the direct flux of $\mathrm{CO}_{2}$ through the plasma membrane (Endeward et al., 2006; Hub and De Groot, 2006). Gliomas predominantly express carbonic anhydrase 9 (CAIX) and aquaporins 1 and 4 (AQP1 and AQP4). Aquaporins 
have also been shown to play roles in glioma cell adhesion and maintenance of iso-osmolarity during volume regulation via $\mathrm{H}_{2} \mathrm{O}$ flux (McCoy and Sontheimer, 2007). The direct role of these proteins in brain tumor pathophysiology is outside the scope of this review.

\section{CONSEQUENCES OF $\mathrm{pH}$ i REGULATION}

The most direct (and obvious) consequence of $\mathrm{pH}_{\mathrm{i}}$ regulation is $\mathrm{pH}_{\mathrm{e}}$ alteration. The aforementioned mechanisms of $\mathrm{pH}_{\mathrm{i}}$ regulation mostly act as intracellular alkalinizing agents, leading to a large proton efflux into the extracellular space (ECS). The magnitude of $\mathrm{pH}_{\mathrm{i}}$ and $\mathrm{pH}_{\mathrm{e}}$ changes depends on buffering capacity, total compartment volume, and molecular diffusivity (Chesler, 2003). These protons do not dissipate readily in the poorly perfused spaces within solid tumors, resulting in $\mathrm{pH}_{\mathrm{e}}$ heterogeneity and pockets of increased acidity. Therefore, protons may serve as messenger molecules that alter both intratumoral and extratumoral physiology (Figure 2). This section will both review known mechanisms of $\mathrm{pH}$-directed pathophysiology in brain tumors as well as draw lessons from other solid tumor types.

\section{ION CHANNEL SIGNALING}

Brain tumors possess several $\mathrm{pH}$-sensitive ion channels, including acid-sensing ion channels (ASICs), transient receptor potential channels (TRPs), two-pore potassium channels (K2Ps), purinergic receptors (P2XRs), and proton-sensing G-protein coupled receptors (GPCRs). Here we will briefly touch upon channel expression, subtype, and $\mathrm{pH}$-sensitivity as discussed in brain tumor literature. For a broader view of $\mathrm{pH}$-sensitive ion channels and cancer, see Glitsch (2011); for a more in-depth view of ion channels in brain tumors, see Ding et al. (2012).

ASICs are cation-nonspecific $\left(\mathrm{Na}^{+}, \mathrm{K}^{+}\right.$, and sometimes $\left.\mathrm{Ca}^{2+}\right)$ ion channels that are usually opened by low $\mathrm{pH}_{\mathrm{e}}$ and are

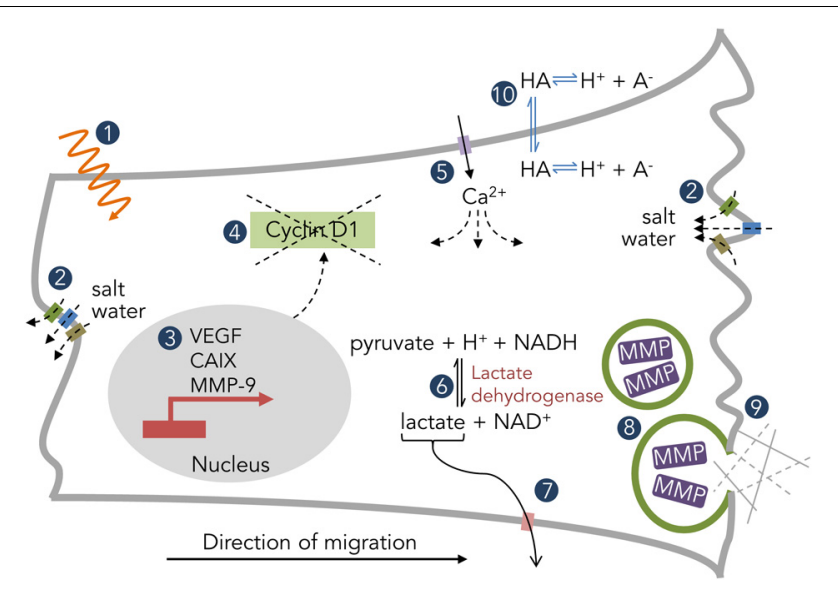

FIGURE 2 | Examples of pH-dependent physiology in solid tumors. (1) Radiation efficacy. (2) Salt water flux via $\mathrm{K}^{+}, \mathrm{Cl}^{-}$, and $\mathrm{H}_{2} \mathrm{O}$ channels. (3) Downstream expression patterns of tumorigenic genes. (4) Mislocalization of cyclin D1 and disruption of the cell cycle. (5) $\mathrm{Ca}^{2+}$ permeation through ion channels (ASIC, P2X, TRP) and subsequent downstream effects. (6) Metabolic enzyme activity. (7) $\mathrm{H}^{+}$-coupled lactate efflux. (8) Vesicular fusion and protease enzymatic activity. (9) Interaction with the extracellular matrix. (10) Distribution of weak acids/bases. transiently active. ASICs 1 and 2 have been shown to be expressed in human glioma cells (Berdiev et al., 2003), with sensitivity to psalmotoxin 1 in addition to amiloride (Bubien et al., 2004). The $\mathrm{Na}^{+}$current derived from glioma ASIC expression contributes to their volume regulation (Ross et al., 2007) and migration (VilaCarriles et al., 2006; Kapoor et al., 2009). Interestingly, a hybrid of ASIC and epithelial sodium channel $(\mathrm{ENaC})$ subunits creates a basally active conductance (Kapoor et al., 2011) that affects glioma cell migration and cell cycle progression (Rooj et al., 2012). This hybrid channel is recruited to the plasma membrane in the face of acidic $\mathrm{pH}_{\mathrm{e}}$ as found in the tumor core (Kapoor et al., 2011). Under acidotic conditions, the role of ASIC1a and ASIC2a seems paradoxical: ASIC1a knockdown prevents $\mathrm{Ca}^{2+}$-mediated injury (Weng et al., 2007), while ASIC2a knockdown aggravates it (Liu et al., 2011).

TRPs are also cation-nonspecific channels, whose $\mathrm{pH}$ sensitivities play a role in the proton-heavy environments of taste buds, pain receptors, and cancer cells. In brain tumor cells, the expression of TRPC channels has been especially tied to $\mathrm{Ca}^{2+}$ influx mediating changes in cell morphology and movement. This includes cytokinesis (Bomben and Sontheimer, 2008, 2010), $\mathrm{Ca}^{2+}$ mobilization (Nakao et al., 2008; Chigurupati et al., 2010), and cell migration (Chigurupati et al., 2010; Bomben et al., 2011). Unlike TRPC channels, TRPV channel expression tends to negatively affect glioma cells, leaving them vulnerable to capsaicininduced apoptosis (Amantini et al., 2007) and chemotherapeutic cytotoxicity (Nabissi et al., 2013), as well as promoting differentiation (Morelli et al., 2012). Interestingly, neural precursor cells (NPCs) release endogenous TRPV agonists that prevent glioma cells from attacking the juvenile brain (Stock et al., 2012), a phenomenon that is lost with a loss of NPCs during aging.

P2XRs are ATP-gated cation channels, while P2YRs are purinergic-coupled GPCRs. Together, they are most extensively studied for their involvement in $\mathrm{Ca}^{2+}$ flux in glioma cell signal transduction, tumor progression, and cell death. In general, these receptors are proton-potentiated (Glitsch, 2011). For a comprehensive review of purinergic signaling in glioma cells, refer to Barañska (2013); for the $\mathrm{pH}$-sensitivities of these channels, refer to Stoop et al. (1997), Gerevich et al. (2007).

$\mathrm{K} 2 \mathrm{P}$ channels and $\mathrm{pH}$-sensitive GPCRs have not been studied extensively in brain tumor tissue, though their roles in other cancers have been elucidated (Sin et al., 2004; Innamaa et al., 2013). The K2P members TASK-1 and TASK-3, pH-sensitive background $\mathrm{K}^{+}$channels, have functional expression in human medulloblastoma cells (Ernest et al., 2010) and have been functionally implicated in glioma cell survival (Meuth et al., 2008). The $\mathrm{pH}$-sensitive GPCRs OGR1 and G2A are also expressed in human medulloblastoma cells and regulate intracellular $\mathrm{Ca}^{2+}$ signaling in response to extracellular pH (Huang et al., 2008).

\section{VOLUME REGULATION AND CELL MOVEMENT}

Gliomas are highly invasive, quickly seeding the brain with satellite tumors. This is especially impressive in the crowded brain space and requires a coordinated effort of cell shrinkage, process extension, and path-clearing. Volume regulation is a vital component of the first two functions and requires salt water flux (cation + anion $+\mathrm{H}_{2} \mathrm{O}$; Figure 2) (Sontheimer, 2008; 
Watkins and Sontheimer, 2011). Two of the most well-studied ion channels in glioma cell migration, $\mathrm{BK}$ for $\mathrm{K}^{+}$ions and $\mathrm{ClC}-3$ for $\mathrm{Cl}^{-}$ions, are $\mathrm{pH}$-sensitive. More specifically, low $\mathrm{pH}_{\mathrm{e}}$ blocks both channels, while low $\mathrm{pH}_{\mathrm{i}}$ stimulates $\mathrm{BK}$ channels, all within a physiological range of $\mathrm{pH}$ 6-8 (Avdonin et al., 2003; Brelidze and Magleby, 2004; Matsuda et al., 2008, 2010). Additionally, as described beforehand, proton flux through glioma cells is directly tied to osmotically-active $\mathrm{Na}^{+}$and lactate, which both then contribute to volume regulation (Jakubovicz and Klip, 1989; Staub et al., 1990). Thus, protons can both directly and indirectly contribute to glioma cell volume regulation, which then affects cell movement.

Proton concentrations also both alter shape and orient tumor cells. This has been most thoroughly studied regarding NHE in melanoma cells, though gliomas similarly possess increased NHE1 activity versus their non-transformed counterparts (McLean et al., 2000) with specific microdomain localization (Willoughby et al., 2005). In melanoma cells, NHE1 creates a local $\mathrm{pH}$ gradient that dominates the bulk solution $\mathrm{pH}$ and orients the cells via $\mathrm{pH}$-dependence of integrin $\alpha 2 \beta 1$ stickiness (Stock et al., 2005; Stuwe et al., 2007; Martin et al., 2011). Intracellularly, NHE1 also organizes the cytoskeleton of cells. For instance, the Rho GTPase Cdc42 recruits NHE1 to the leading edge of the cell, increasing leading edge $\mathrm{pH}_{\mathrm{i}}$ and activating $\mathrm{Cdc} 42$ via a guanine nucleotide exchange factor, thus, maintaining polarized cytoskeletal growth (Frantz et al., 2007). Similarly, cortactin phosphorylation recruits NHE1 to the invadopodium, where it alkalinizes $\mathrm{pH}_{\mathrm{i}}$ and induces actin polymerization via cortactin release of cofilin (Magalhaes et al., 2011), thus playing an integral role in invadopodium protrusion/retraction cycling. NHE1 is further activated at the invadopodium by $\mathrm{p} 90$ ribosomal $\$ 6$ kinase under hypoxic conditions (Lucien et al., 2011).

\section{TISSUE DESTRUCTION}

Brain tumors also cause direct destruction of surrounding tissue, including both neuronal death via glutamate excitotoxicity (Ye and Sontheimer, 1999) and degradation of the extracellular matrix via metalloproteinases (MMPs) and other proteases (Nakada et al., 2003). It is well-established that protease activity is pH-dependent (Fasciglione et al., 2000; Gioia et al., 2010). Additionally, however, acidic $\mathrm{pH}_{\mathrm{e}}$ both induces MMP-9 expression (Kato et al., 2005) and enhances the rupture of proteasecontaining vesicles (Taraboletti et al., 2006), hinting at acidosis driving tumor invasion (Figure 2). RNAi inhibition of MMP9 and the protease cathepsin B dramatically reduced tumor pathogenicity of gliomas both in vitro and in vivo (Lakka et al., 2004).

Here again NHE1 plays a role. While in the intracellular compartment NHE1-dependent alkalinization coordinates tumor cell invasion, in the extracellular compartment the consequent acidification is essential for proteolysis of the extracellular matrix (Busco et al., 2010). Interestingly, preventing ion translocation through NHE1 alone was sufficient to alter the gene profile of mammalian fibroblasts, including a decrease in MMP-9 expression (Putney and Barber, 2004).

Finally, the excitotoxic process is itself $\mathrm{pH}$-dependent. Excitatory amino acid transporter 2 (EAAT-2), expressed in low-grade brain tumors (De Groot et al., 2005), cotransports protons along with glutamate and thus is $\mathrm{pH}$-dependent (Vandenberg et al., 1998). The alanine-cysteine-serine transporter 2 (ASCT2) also transports glutamate, and it has shown $\mathrm{pH}$ dependence in C6 glioma cells (Doliñska et al., 2003). Lastly, the NMDA glutamate receptors in part responsible for neuronal excitotoxicity are inhibited by protons (Traynelis and Cull-Candy, 1990).

\section{METABOLIC ACTIVITY}

Gliomas, like most other cancers, demonstrate the Warburg effect-a preference for glycolysis over oxidative phosphorylation even in the presence of ample oxygen. This leads to increased intracellular lactate buildup, which is cleared via the cotransport of lactate and protons via MCTs (Figure 2). Thus, inhibition of these cotransporters via drug or decreased $\mathrm{pH}_{\mathrm{e}}$ both decreases $\mathrm{pH}_{\mathrm{i}}$ (Volk et al., 1997) and increases intracellular lactate levels (Lomneth et al., 1990). As many glycolytic enzymes prefer the slightly alkaline $\mathrm{pH}_{\mathrm{i}}$ of glioma cells-lactate dehydrogenase displays maximal activity at $\mathrm{pH}_{\mathrm{i}} 7.5$ while phosphofructokinase 1 works best between $\mathrm{pH}_{\mathrm{i}} 7.0$ and 7.5 (Webb et al., 2011)there is an intimate coupling of glioma $\mathrm{pH}$ regulation and cell metabolism. This connection likely governs the expression patterns of $\mathrm{pH}$-associated proteins across the glioma mass (Grillon et al., 2011).

\section{CELL SIGNALING}

It is often difficult to separate the consequences of the various conditions found within a tumor; levels of $\mathrm{CO}_{2}, \mathrm{O}_{2}$, lactate, waste products, and $\mathrm{pH}$ distribute through the tumor heterogeneously, and all can influence the cellular phenotype. A few studies have specifically implicated acidosis in an alteration of glioma cell state. For instance, a $\mathrm{pH}_{\mathrm{e}}$ of 6.6 upregulated VEGF mRNA and protein expression in human GBM cells via the ERK1/2 MAPK signaling cascade (Xu et al., 2002). Acidosis $\left(\mathrm{pH}_{\mathrm{e}}\right.$ 6.5) also maintained the stemness of glioma cells as determined both by stem cell markers and cellular phenotype via hypoxia inducible factor $2 \alpha$ (HIF2 $\alpha$ ) signaling (Hjelmeland et al., 2011). Acyl-CoA synthetase 5 (ACSL5) promotes glioma cell survival under low $\mathrm{pH}_{\mathrm{e}}$ conditions through midkine (MDK) signaling (Mashima et al., 2009). CA IX, known to be upregulated during times of hypoxia via the HIF1 $\alpha$ pathway (Wykoff et al., 2000), is also upregulated by low $\mathrm{pH}_{\mathrm{e}}$ independent of hypoxia in GBM cells via the same pathway (Ihnatko et al., 2006). Finally, very low $\mathrm{pH}_{\mathrm{e}}$ (6.0) arrested glioma cells in the $G_{1}$ phase of the cell cycle as a downstream result of cyclin $\mathrm{D}_{1}$ mislocalization (Figure 2) and degradation in T98G human glioma cells (Schnier et al., 2008).

\section{THERAPY SENSITIVITY}

A heterogeneous $\mathrm{pH}$ environment creates a moving target for both radiation and chemotherapeutics. Weak base and weak acid drugs find themselves confined to either the intracellular or extracellular spaces (Figure 2), depending on $\mathrm{pH}_{\mathrm{e}}$ and $\mathrm{pH}_{\mathrm{i}}$, in a phenomenon known as "ion trapping" (Raghunand and Gillies, 2000). This can result in heterogeneous drug potency across the tumor mass, and has led to efforts to either acidify or alkalinize the tumor in an attempt to localize chemotherapeutics to either 
the intra- or extracellular compartment. In gliomas, mild acidosis inhibits cell growth while protecting cells from chemotherapeutic cytotoxicity (Reichert et al., 2002). Attempts have been made to artificially alkalinize solid tumors with $\mathrm{NaHCO}_{3}$-induced metabolic alkalosis to enhance weak base uptake (Raghunand et al., 2001), though none of these studies have yet been performed in brain tumors. $\mathrm{pH}$ also can affect the radiosensitivity of cells (Bosi et al., 1991), though its effect on glioma cells appears inconsistent (Reichert et al., 2002).

With highly buffered ions such as $\mathrm{Ca}^{2+}$ and protons, nanomolar changes in the free ion concentration equate to severalfold shifts and drastic changes in central nervous system (CNS) signaling. It is this context that separates brain tumors from other solid tumors - the pathophysiological implications of large $\mathrm{pH}$ heterogeneity in a susceptible environment are greater than in many other, more robust organs. This also leads to great opportunitybrain tumors lean heavily on $\mathrm{pH}$ regulation to continue their growth and invasion, and thus disruption of proton transport could devastate tumor function while leaving normal tissue relatively unharmed.

\section{REFERENCES}

Acker, H., Holtermann, G., Bolling, B., and Carlsson, J. (1992). Influence of glucose on metabolism and growth of rat glioma cells (C6) in multicellular spheroid culture. Int. J. Cancer 52, 279-285. doi: 10.1002/ijc.2910520221

Aickin, C. C., and Thomas, R. C. (1977). An investigation of the ionic mechanism of intracellular $\mathrm{pH}$ regulation in mouse soleus muscle fibres. J. Physiol. 273, 295-316.

Amantini, C., Mosca, M., Nabissi, M., Lucciarini, R., Caprodossi, S., Arcella, A., et al. (2007). Capsaicin-induced apoptosis of glioma cells is mediated by TRPV1 vanilloid receptor and requires p38 MAPK activation. J. Neurochem. 102, 977-990. doi: 10.1111/j.1471-4159.2007.04582.x

Avdonin, V., Tang, X. D., and Hoshi, T. (2003). Stimulatory action of internal protons on Slol BK channels. Biophys. J. 84, 2969-2980. doi: 10.1016/S00063495(03)70023-X

Barañska, J. (2013). Glioma Signaling. Dordrecht: Springer. doi: 10.1007/978-94007-4719-7

Berdiev, B. K., Xia, J., McLean, L. A., Markert, J. M., Gillespie, G. Y., Mapstone, T. B., et al. (2003). Acid-sensing ion channels in malignant gliomas. J. Biol. Chem. 278, 15023-15034. doi: 10.1074/jbc.M300991200

Bevensee, M. O., and Boron, W. F. (2013). "Control of intracellular $\mathrm{pH}$," in Seldin and Giebisch's The Kidney 5th Edn., Chapter 52, eds R. J. Alpern, O. W. Moe, and M. Caplan (Oxford: Academic Press), 1773-1835.

Blough, M. D., Al-Najjar, M., Chesnelong, C., Binding, C. E., Rogers, A. D., Luchman, H. A., et al. (2012). DNA hypermethylation and $1 p$ Loss silence NHE1 in oligodendroglioma. Ann. Neurol. 71, 845-849. doi: 10.1002/ana.23610

Bomben, V. C., and Sontheimer, H. (2010). Disruption of transient receptor potential canonical channel 1 causes incomplete cytokinesis and slows the growth of human malignant gliomas. Glia 58, 1145-1156. doi: 10.1002/glia.20994

Bomben, V. C., and Sontheimer, H. W. (2008). Inhibition of transient receptor potential canonical channels impairs cytokinesis in human malignant gliomas. Cell Prolif. 41, 98-121. doi: 10.1111/j.1365-2184.2007.00504.x

Bomben, V. C., Turner, K. L., Barclay, T. T., and Sontheimer, H. (2011). Transient receptor potential canonical channels are essential for chemotactic migration of human malignant gliomas. J. Cell. Physiol. 226, 1879-1888. doi: $10.1002 /$ jcp. 22518

Bosi, A., Micheli, A., Pietrosanti, S., and Olivieri, G. (1991). Effect of pH shifts on radiosensitivity of human lymphocytes irradiated in the G2 stage. Mutat. Res. 250, 325-329. doi: 10.1016/0027-5107(91)90188-T

Brelidze, T. I., and Magleby, K. L. (2004). Protons block BK channels by competitive inhibition with $\mathrm{K}+$ and contribute to the limits of unitary currents at high voltages. J. Gen. Physiol. 123, 305-319. doi: 10.1085/jgp.200308951

Bubien, J. K., Ji, H. L., Gillespie, G. Y., Fuller, C. M., Markert, J. M., Mapstone, T. B., et al. (2004). Cation selectivity and inhibition of malignant glioma $\mathrm{Na}+$ channels by Psalmotoxin 1. Am. J. Physiol. Cell Physiol. 287, C1282-C1291. doi: 10.1152/ajpcell.00077.2004

Busco, G., Cardone, R. A., Greco, M. R., Bellizzi, A., Colella, M., Antelmi, E., et al. (2010). NHE1 promotes invadopodial ECM proteolysis through acidification of the peri-invadopodial space. FASEB J. 24, 3903-3915. doi: 10.1096/fj.09149518

Charles, N. A., Holland, E. C., Gilbertson, R., Glass, R., and Kettenmann, H. (2011). The brain tumor microenvironment. Glia 59, 1169-1180. doi: 10.1002/glia.21136

Chesler, M. (2003). Regulation and modulation of pH in the brain. Physiol. Rev. 83, 1183-1221. doi: 10.1152/physrev.00010.2003

Chigurupati, S., Venkataraman, R., Barrera, D., Naganathan, A., Madan, M., Paul, L., et al. (2010). Receptor channel TRPC6 is a key mediator of Notchdriven glioblastoma growth and invasiveness. Cancer Res. 70, 418-427. doi: 10.1158/0008-5472.CAN-09-2654

De Groot, J. F., Liu, T. J., Fuller, G., and Yung, W. K. A. (2005). The excitatory amino acid transporter-2 induces apoptosis and decreases glioma growth In vitro and In vivo. Cancer Res. 65, 1934-1940. doi: 10.1158/0008-5472.CAN-04-3626

Ding, X., He, H., Lu, Y., and Wang, Y. (2012). Ionic Channels in the Therapy of Malignant Glioma, Shanghai: InTech.

Doliñska, M., Dybel, A., Zabłocka, B., and Albrecht, J. (2003). Glutamine transport in C6 glioma cells shows ASCT2 system characteristics. Neurochem. Int. 43, 501-507. doi: 10.1016/S0197-0186(03)00040-8

Dringen, R., Peters, H., Wiesinger, H., and Hamprecht, B. (1995). Lactate transport in cultured glial cells. Dev. Neurosci. 17, 63-69. doi: 10.1159/000111275

Endeward, V., Musa-Aziz, R., Cooper, G. J., Chen, L. M., Pelletier, M. F., Virkki, L. V., et al. (2006). Evidence that aquaporin 1 is a major pathway for CO2 transport across the human erythrocyte membrane. FASEB J. 20, 1974-1981. doi: 10.1096/fi.04-3300com

Ernest, N. J., Logsdon, N. J., McFerrin, M. B., Sontheimer, H., and Spiller, S. E. (2010). Biophysical properties of human medulloblastoma cells. J. Membr. Biol. 237, 59-69. doi: 10.1007/s00232-010-9306-x

Fasciglione, G. F., Marini, S., D’alessio, S., Politi, V., and Coletta, M. (2000). pHand temperature-dependence of functional modulation in metalloproteinases. A comparison between neutrophil collagenase and gelatinases A and B. Biophys. J. 79, 2138-2149. doi: 10.1016/S0006-3495(00)76461-7

Frantz, C., Karydis, A., Nalbant, P., Hahn, K. M., and Barber, D. L. (2007). Positive feedback between Cdc42 activity and $\mathrm{H}+$ efflux by the $\mathrm{Na}-\mathrm{H}$ exchanger NHE1 for polarity of migrating cells. J. Cell Biol. 179, 403-410. doi: 10.1083/jcb.200704169

Froberg, M. K., Gerhart, D. Z., Enerson, B. E., Manivel, C., Guzman-Paz, M., Seacotte, N., et al. (2001). Expression of monocarboxylate transporter MCT1 in normal and neoplastic human CNS tissues. Neuroreport 12, 761-765. doi: 10.1097/00001756-200103260-00030

Gerard, V., Rouzaire-Dubois, B., Dilda, P., and Dubois, J. M. (1998). Alterations of ionic membrane permeabilities in multidrug-resistant neuroblastoma $\mathrm{x}$ glioma hybrid cells. J. Exp. Biol. 201, 21-31.

Gerard, V., Rouzaire-Dubois, B., and Dubois, J. M. (1994). Contribution of a H+ pump in determining the resting potential of neuroblastoma cells. J. Membr. Biol. 137, 119-125. doi: 10.1007/BF00233481

Gerevich, Z., Zadori, Z. S., Koles, L., Kopp, L., Milius, D., Wirkner, K., et al. (2007). Dual effect of acid $\mathrm{pH}$ on purinergic $\mathrm{P} 2 \mathrm{X} 3$ receptors depends on the histidine 206 residue. J. Biol. Chem. 282, 33949-33957. doi: 10.1074/jbc.M705840200

Gioia, M., Fasciglione, G. F., Monaco, S., Iundusi, R., Sbardella, D., Marini, S., et al. (2010). $\mathrm{pH}$ dependence of the enzymatic processing of collagen I by MMP1 (fibroblast collagenase), MMP-2 (gelatinase A), and MMP-14 ectodomain. J. Biol. Inorg. Chem. 15, 1219-1232. doi: 10.1007/s00775-010-0680-8

Gleize, V., Boisselier, B., Marie, Y., Poea-Guyon, S., Sanson, M., and Morel, N. (2012). The renal v-ATPase a4 subunit is expressed in specific subtypes of human gliomas. Glia 60, 1004-1012. doi: 10.1002/glia.22332

Glitsch, M. (2011). Protons and Ca2+: ionic allies in tumor progression? Physiology 26, 252-265. doi: 10.1152/physiol.00005.2011

Glunde, K., Dussmann, H., Juretschke, H. P., and Leibfritz, D. (2002). $\mathrm{Na}(+) / \mathrm{H}(+)$ exchange subtype 1 inhibition during extracellular acidification and hypoxia in glioma cells. J. Neurochem. 80, 36-44. doi: 10.1046/j.0022-3042. 2001.00661.x

Grillon, E., Farion, R., Fablet, K., De Waard, M., Tse, C. M., Donowitz, M., et al. (2011). The spatial organization of proton and lactate transport in a rat brain tumor. PLoS ONE 6:e17416. doi: 10.1371/journal.pone.0017416 
Grobben, B., De Deyn, P. P., and Slegers, H. (2002). Rat C6 glioma as experimental model system for the study of glioblastoma growth and invasion. Cell Tissue Res. 310, 257-270. doi: 10.1007/s00441-002-0651-7

Hegde, M., Roscoe, J., Cala, P., and Gorin, F. (2004). Amiloride kills malignant glioma cells independent of its inhibition of the sodium-hydrogen exchanger. J. Pharmacol. Exp. Ther. 310, 67-74. doi: 10.1124/jpet.103.065029

Hertel, C., and Staehelin, M. (1983). Reappearance of beta-adrenergic receptors after isoproterenol treatment in intact C6-cells. J. Cell Biol. 97, 1538-1543. doi: 10.1083/jcb. 97.5 .1538

Hjelmeland, A. B., Wu, Q., Heddleston, J. M., Choudhary, G. S., Macswords, J., Lathia, J. D., et al. (2011). Acidic stress promotes a glioma stem cell phenotype. Cell Death Differ. 18, 829-840. doi: 10.1038/cdd.2010.150

Huang, W. C., Swietach, P., Vaughan-Jones, R. D., Ansorge, O., and Glitsch, M. D. (2008). Extracellular acidification elicits spatially and temporally distinct Ca2+ signals. Curr. Biol. 18, 781-785. doi: 10.1016/j.cub.2008.04.049

Hub, J. S., and De Groot, B. L. (2006). Does CO2 permeate through aquaporin-1? Biophys. J. 91, 842-848. doi: 10.1529/biophysj.106.081406

Ihnatko, R., Kubes, M., Takacova, M., Sedlakova, O., Sedlak, J., Pastorek, J., et al. (2006). Extracellular acidosis elevates carbonic anhydrase IX in human glioblastoma cells via transcriptional modulation that does not depend on hypoxia. Int J. Oncol. 29, 1025-1033.

Innamaa, A., Jackson, L., Asher, V., Van Schalkwyk, G., Warren, A., Keightley, A., et al. (2013). Expression and effects of modulation of the K2P potassium channels TREK-1 (KCNK2) and TREK-2 (KCNK10) in the normal human ovary and epithelial ovarian cancer. Clin. Transl. Oncol. 15, 910-918. doi: 10.1007/s12094-013-1022-4

Irani, D. N. (2008). Cerebrospinal Fluid in Clinical Practice. Philadelphia: Elsevier Health Sciences.

Isom, L. L., Cragoe, E. J. Jr., and Limbird, L. E. (1987a). Alpha 2-adrenergic receptors accelerate $\mathrm{Na}+/ \mathrm{H}+$ exchange in neuroblastoma X glioma cells. J. Biol. Chem. $262,6750-6757$.

Isom, L. L., Cragoe, E. J. Jr., and Limbird, L. E. (1987b). Multiple receptors linked to inhibition of adenylate cyclase accelerate $\mathrm{Na}+\mathrm{H}+$ exchange in neuroblastoma $\mathrm{x}$ glioma cells via a mechanism other than decreased cAMP accumulation. J. Biol. Chem. 262, 17504-17509.

Jakubovicz, D. E., Grinstein, S., and Klip, A. (1987). Cell swelling following recovery from acidification in C6 glioma cells: an in vitro model of postischemic brain edema. Brain Res. 435, 138-146. doi: 10.1016/0006-8993(87)91594-0

Jakubovicz, D. E., and Klip, A. (1989). Lactic acid-induced swelling in C6 glial cells via $\mathrm{Na}+\mathrm{H}+$ exchange. Brain Res. 485, 215-224. doi: 10.1016/00068993(89)90564-7

Kapoor, N., Bartoszewski, R., Qadri, Y. J., Bebok, Z., Bubien, J. K., Fuller, C. M., et al. (2009). Knockdown of ASIC1 and epithelial sodium channel subunits inhibits glioblastoma whole cell current and cell migration. J. Biol. Chem. 284 24526-24541. doi: 10.1074/jbc.M109.037390

Kapoor, N., Lee, W., Clark, E., Bartoszewski, R., McNicholas, C. M., Latham, C. B., et al. (2011). Interaction of ASIC1 and ENaC subunits in human glioma cells and rat astrocytes. Am. J. Physiol. Cell Physiol. 300, C1246-C1259. doi: 10.1152/ajpcell.00199.2010

Kato, Y., Lambert, C. A., Colige, A. C., Mineur, P., Noel, A., Frankenne, F., et al. (2005). Acidic extracellular $\mathrm{pH}$ induces matrix metalloproteinase-9 expression in mouse metastatic melanoma cells through the phospholipase D-mitogenactivated protein kinase signaling. J. Biol. Chem. 280, 10938-10944. doi: 10.1074/jbc.M411313200

Kempski, O., Staub, F., Jansen, M., and Baethmann, A. (1990). Molecular mechanisms of glial cell swelling in acidosis. Adv. Neurol. 52, 39-45.

Kempski, O., Staub, F., Jansen, M., Schodel, F., and Baethmann, A. (1988). Glial swelling during extracellular acidosis in vitro. Stroke 19, 385-392. doi: 10.1161/01.STR.19.3.385

Kislin, K. L., McDonough, W. S., Eschbacher, J. M., Armstrong, B. A., and Berens, M. E. (2009). NHERF-1: modulator of glioblastoma cell migration and invasion. Neoplasia 11,377-387.

Lakka, S. S., Gondi, C. S., Yanamandra, N., Olivero, W. C., Dinh, D. H., Gujrati, M., et al. (2004). Inhibition of cathepsin B and MMP-9 gene expression in glioblastoma cell line via RNA interference reduces tumor cell invasion, tumor growth and angiogenesis. Oncogene 23, 4681-4689. doi: 10.1038/sj.onc.1207616

Liu, X. Y., Zhang, S. Z., Ma, X. Y., Wang, H., Wu, B. H., Sun, H. L., et al. (2011). Knockdown of ASIC2a subunit aggravates injury of rat C6 glioma cells in acidosis. J. Physiol. Biochem. 67, 275-281. doi: 10.1007/s13105-010-0060-4
Lomneth, R., Medrano, S., and Gruenstein, E. I. (1990). The role of transmembrane $\mathrm{pH}$ gradients in the lactic acid induced swelling of astrocytes. Brain Res. 523, 69-77. doi: 10.1016/0006-8993(90)91636-U

Lucien, F., Brochu-Gaudreau, K., Arsenault, D., Harper, K., and Dubois, C. M. (2011). Hypoxia-induced invadopodia formation involves activation of NHE-1 by the p90 ribosomal S6 kinase (p90RSK). PLoS ONE 6:e28851. doi: 10.1371/journal.pone.0028851

Lui, C. P., Fung, K. P., Kong, S. K., Choy, Y. M., and Lee, C. Y. (1995). Effect of hyperthermia on intracellular pH in human U-87 MG glioblastoma cells. Oncology 52, 492-497. doi: 10.1159/000227517

Lust, W. D., Schwartz, J. P., and Passonneau, J. V. (1975). Glycolytic metabolism in cultured cells of the nervous system. I. Glucose transport and metabolism in the C-6 glioma cell line. Mol. Cell. Biochem. 8, 169-176. doi: 10.1007/BF01792767

Mac, M., and Nalecz, K. A. (2003). Expression of monocarboxylic acid transporters (MCT) in brain cells. Implication for branched chain alpha-ketoacids transport in neurons. Neurochem. Int. 43, 305-309. doi: 10.1016/S0197-0186(03)00016-0

Magalhaes, M. A., Larson, D. R., Mader, C. C., Bravo-Cordero, J. J., GilHenn, H., Oser, M., et al. (2011). Cortactin phosphorylation regulates cell invasion through a pH-dependent pathway. J. Cell Biol. 195, 903-920. doi: $10.1083 /$ jcb. 201103045

Martin, C., Pedersen, S. F., Schwab, A., and Stock, C. (2011). Intracellular pH gradients in migrating cells. Am. J. Physiol. Cell Physiol. 300, C490-C495. doi: 10.1152/ajpcell.00280.2010

Mashima, T., Sato, S., Sugimoto, Y., Tsuruo, T., and Seimiya, H. (2009). Promotion of glioma cell survival by acyl-CoA synthetase 5 under extracellular acidosis conditions. Oncogene 28, 9-19. doi: 10.1038/onc.2008.355

Matsuda, J. J., Filali, M. S., Collins, M. M., Volk, K. A., and Lamb, F. S. (2010). The ClC-3 Cl-/H+ antiporter becomes uncoupled at low extracellular pH. J. Biol. Chem. 285, 2569-2579. doi: 10.1074/jbc.M109.018002

Matsuda, J. J., Filali, M. S., Volk, K. A., Collins, M. M., Moreland, J. G., and Lamb, F. S. (2008). Overexpression of CLC-3 in HEK293T cells yields novel currents that are pH dependent. Am. J. Physiol. Cell Physiol. 294, C251-C262. doi: 10.1152/ajpcell.00338.2007

McCoy, E., and Sontheimer, H. (2007). Expression and function of water channels (aquaporins) in migrating malignant astrocytes. Glia 55, 1034-1043. doi: 10.1002/glia.20524

McLean, L. A., Roscoe, J., Jorgensen, N. K., Gorin, F. A., and Cala, P. M. (2000). Malignant gliomas display altered $\mathrm{pH}$ regulation by NHE1 compared with nontransformed astrocytes. Am. J. Physiol. Cell Physiol. 278, C676-C688.

Meuth, S. G., Herrmann, A. M., Ip, C. W., Kanyshkova, T., Bittner, S., Weishaupt, A., et al. (2008). The two-pore domain potassium channel TASK3 functionally impacts glioma cell death. J. Neurooncol. 87, 263-270. doi: 10.1007/s11060-0089517-5

Miranda-Goncalves, V., Honavar, M., Pinheiro, C., Martinho, O., Pires, M. M., Pinheiro, C., et al. (2013). Monocarboxylate transporters (MCTs) in gliomas: expression and exploitation as therapeutic targets. Neurooncology 15, 172-188. doi: 10.1093/neuonc/nos 298

Morelli, M. B., Nabissi, M., Amantini, C., Farfariello, V., Ricci-Vitiani, L., Di Martino, S., et al. (2012). The transient receptor potential vanilloid-2 cation channel impairs glioblastoma stem-like cell proliferation and promotes differentiation. Int. J. Cancer 131, E1067-E1077. doi: 10.1002/ijc.27588

Mountian, I., Chou, K. Y., and Van Driessche, W. (1996). Electrolyte transport mechanisms involved in regulatory volume increase in C6 glioma cells. Am. J. Physiol. 271, C1041-C1048.

Nabissi, M., Morelli, M. B., Santoni, M., and Santoni, G. (2013). Triggering of the TRPV2 channel by cannabidiol sensitizes glioblastoma cells to cytotoxic chemotherapeutic agents. Carcinogenesis 34, 48-57. doi: 10.1093/carcin/ bgs 328

Nakada, M., Okada, Y., and Yamashita, J. (2003). The role of matrix metalloproteinases in glioma invasion. Front. Biosci. 8:e261-269. doi: 10.2741/1016

Nakao, K., Shirakawa, H., Sugishita, A., Matsutani, I., Niidome, T., Nakagawa, T., et al. (2008). Ca2+ mobilization mediated by transient receptor potential canonical 3 is associated with thrombin-induced morphological changes in 1321N1 human astrocytoma cells. J. Neurosci. Res. 86, 2722-2732. doi: 10.1002/jnr.21711

Neve, K. A., Kozlowski, M. R., and Rosser, M. P. (1992). Dopamine D2 receptor stimulation of $\mathrm{Na}+/ \mathrm{H}+$ exchange assessed by quantification of extracellular acidification. J. Biol. Chem. 267, 25748-25753. 
Nunnari, J. M., Repaske, M. G., Brandon, S., Cragoe, E. J. Jr., and Limbird, L. E. (1987). Regulation of porcine brain alpha 2-adrenergic receptors by $\mathrm{Na}+\mathrm{H}+$ and inhibitors of $\mathrm{Na}+/ \mathrm{H}+$ exchange. J. Biol. Chem. 262, 12387-12392.

Philippe, J. M., Dubois, J. M., Rouzaire-Dubois, B., Cartron, P. F., Vallette, F., and Morel, N. (2002). Functional expression of V-ATPases in the plasma membrane of glial cells. Glia 37, 365-373. doi: 10.1002/glia.10041

Putney, L. K., and Barber, D. L. (2004). Expression profile of genes regulated by activity of the Na-H exchanger NHE1. BMC Genomics 5:46. doi: 10.1186/14712164-5-46

Raghunand, N., and Gillies, R. J. (2000). pH and drug resistance in tumors. Drug Resist. Updat. 3, 39-47. doi: 10.1054/drup.2000.0119

Raghunand, N., Mahoney, B., Van Sluis, R., Baggett, B., and Gillies, R. J. (2001). Acute metabolic alkalosis enhances response of $\mathrm{C} 3 \mathrm{H}$ mouse mammary tumors to the weak base mitoxantrone. Neoplasia 3, 227-235. doi: 10.1038/sj.neo.7900151

Reichert, M., Steinbach, J. P., Supra, P., and Weller, M. (2002). Modulation of growth and radiochemosensitivity of human malignant glioma cells by acidosis. Cancer 95, 1113-1119. doi: 10.1002/cncr.10767

Rooj, A. K., McNicholas, C. M., Bartoszewski, R., Bebok, Z., Benos, D. J., and Fuller, C. M. (2012). Glioma-specific cation conductance regulates migration and cell cycle progression. J. Biol. Chem. 287, 4053-4065. doi: 10.1074/jbc.M111.311688

Ross, S. B., Fuller, C. M., Bubien, J. K., and Benos, D. J. (2007). Amiloridesensitive $\mathrm{Na}+$ channels contribute to regulatory volume increases in human glioma cells. Am. J. Physiol. Cell Physiol. 293, C1181-C1185. doi: 10.1152/ajpcell. 00066.2007

Schnier, J. B., Nishi, K., Harley, W. R., and Gorin, F. A. (2008). An acidic environment changes cyclin D1 localization and alters colony forming ability in gliomas. J. Neurooncol. 89, 19-26. doi: 10.1007/s11060-008-9591-8

Shrode, L. D., and Putnam, R. W. (1994). Intracellular $\mathrm{pH}$ regulation in primary rat astrocytes and C6 glioma cells. Glia 12, 196-210. doi: 10.1002/glia.440120305

Sin, W. C., Zhang, Y., Zhong, W., Adhikarakunnathu, S., Powers, S., Hoey, T., et al. (2004). G protein-coupled receptors GPR4 and TDAG8 are oncogenic and overexpressed in human cancers. Oncogene 23, 6299-6303. doi: $10.1038 /$ sj.onc. 1207838

Sontheimer, H. (2008). An unexpected role for ion channels in brain tumor metastasis. Exp. Biol. Med. 233, 779-791. doi: 10.3181/0711-MR-308

Staub, F., Baethmann, A., Peters, J., Weigt, H., and Kempski, O. (1990). Effects of lactacidosis on glial cell volume and viability. J. Cereb. Blood Flow Metab. 10, 866-876. doi: 10.1038/jcbfm.1990.143

Staub, F., Mackert, B., Kempski, O., Haberstok, J., Peters, J., and Baethmann, A. (1994). Swelling and damage to nerves and glial cells by acidosis. Anasthesiol. Intensivmed. Notfallmed. Schmerzther. 29, 203-209. doi: 10.1055/s2007-996719

Stock, C., Gassner, B., Hauck, C. R., Arnold, H., Mally, S., Eble, J. A., et al. (2005). Migration of human melanoma cells depends on extracellular $\mathrm{pH}$ and $\mathrm{Na}+/ \mathrm{H}+$ exchange. J. Physiol. 567, 225-238. doi: 10.1113/jphysiol.2005.088344

Stock, K., Kumar, J., Synowitz, M., Petrosino, S., Imperatore, R., Smith, E. S., et al. (2012). Neural precursor cells induce cell death of high-grade astrocytomas through stimulation of TRPV1. Nat. Med. 18, 1232-1238. doi: 10.1038/nm.2827

Stoop, R., Surprenant, A., and North, R. A. (1997). Different sensitivities to pH of ATP-induced currents at four cloned P2X receptors. J. Neurophysiol. 78, 1837-1840.

Stuwe, L., Muller, M., Fabian, A., Waning, J., Mally, S., Noel, J., et al. (2007). pH dependence of melanoma cell migration: protons extruded by NHE1 dominate protons of the bulk solution. J. Physiol. 585, 351-360. doi: 10.1113/jphysiol.2007.145185

Taraboletti, G., D’ascenzo, S., Giusti, I., Marchetti, D., Borsotti, P., Millimaggi, D., et al. (2006). Bioavailability of VEGF in tumor-shed vesicles depends on vesicle burst induced by acidic pH. Neoplasia 8, 96-103. doi: 10.1593/neo.05583

Tomsig, J. L., Gruenstein, E., and Dimlich, R. V. (1991). Inhibition of lactateinduced swelling by dichloroacetate in human astrocytoma cells. Brain Res. 568 92-100. doi: 10.1016/0006-8993(91)91383-C
Traynelis, S. F., and Cull-Candy, S. G. (1990). Proton inhibition of N-methylD-aspartate receptors in cerebellar neurons. Nature 345, 347-350. doi: $10.1038 / 345347 \mathrm{a} 0$

Vandenberg, R. J., Mitrovic, A. D., and Johnston, G. A. (1998). Serine-O-sulphate transport by the human glutamate transporter, EAAT2. Br. J. Pharmacol. 123, 1593-1600. doi: 10.1038/sj.bjp.0701776

Vila-Carriles, W. H., Kovacs, G. G., Jovov, B., Zhou, Z. H., Pahwa, A. K., Colby, G., et al. (2006). Surface expression of ASIC2 inhibits the amiloride-sensitive current and migration of glioma cells. J. Biol. Chem. 281, 19220-19232. doi: 10.1074/jbc.M603100200

Vlashi, E., Lagadec, C., Vergnes, L., Matsutani, T., Masui, K., Poulou, M., et al. (2011). Metabolic state of glioma stem cells and nontumorigenic cells. Proc. Natl. Acad. Sci. U.S.A. 108, 16062-16067. doi: 10.1073/pnas.1106704108

Volk, C., Albert, T., and Kempski, O. S. (1998). A proton-translocating H+-ATPase is involved in C6 glial pH regulation. Biochim. Biophys. Acta 1372, 28-36. doi: 10.1016/S0005-2736(98)00044-3

Volk, C., Kempski, B., and Kempski, O. S. (1997). Inhibition of lactate export by quercetin acidifies rat glial cells in vitro. Neurosci. Lett. 223, 121-124. doi: 10.1016/S0304-3940(97)13420-6

Watkins, S., and Sontheimer, H. (2011). Hydrodynamic cellular volume changes enable glioma cell invasion. J. Neurosci. 31, 17250-17259. doi: 10.1523/JNEUROSCI.3938-11.2011

Watkins, S., and Sontheimer, H. (2012). Unique biology of gliomas: challenges and opportunities. Trends Neurosci. 35, 546-556. doi: 10.1016/j.tins.2012.05.001

Webb, B. A., Chimenti, M., Jacobson, M. P., and Barber, D. L. (2011). Dysregulated pH: a perfect storm for cancer progression. Nat. Rev. Cancer 11, 671-677. doi: $10.1038 / \mathrm{nrc} 3110$

Weng, X. C., Zheng, J. Q., Li, J., and Xiao, W. B. (2007). Underlying mechanism of ASIC1a involved in acidosis-induced cytotoxicity in rat C6 glioma cells. Acta Pharmacol. Sin. 28, 1731-1736. doi: 10.1111/j.1745-7254.2007.00708.x

Willoughby, D., Masada, N., Crossthwaite, A. J., Ciruela, A., and Cooper, D. M. (2005). Localized $\mathrm{Na}+/ \mathrm{H}+$ exchanger 1 expression protects $\mathrm{Ca} 2+$-regulated adenylyl cyclases from changes in intracellular pH. J. Biol. Chem. 280, 30864-30872. doi: 10.1074/jbc.M414355200

Wykoff, C. C., Beasley, N. J., Watson, P. H., Turner, K. J., Pastorek, J., Sibtain, A., et al. (2000). Hypoxia-inducible expression of tumor-associated carbonic anhydrases. Cancer Res. 60, 7075-7083. doi: 10.1016/S0002-9440 (10)64048-5

Xu, L., Fukumura, D., and Jain, R. K. (2002). Acidic extracellular pH induces vascular endothelial growth factor (VEGF) in human glioblastoma cells via ERK1/2 MAPK signaling pathway: mechanism of low pH-induced VEGF. J. Biol. Chem. 277, 11368-11374. doi: 10.1074/jbc.M108347200

Ye, Z. C., and Sontheimer, H. (1999). Glioma cells release excitotoxic concentrations of glutamate. Cancer Res. 59, 4383-4391.

Conflict of Interest Statement: The authors declare that the research was conducted in the absence of any commercial or financial relationships that could be construed as a potential conflict of interest.

Received: 29 August 2013; paper pending published: 12 September 2013; accepted: 14 October 2013; published online: 01 November 2013.

Citation: Honasoge A and Sontheimer H (2013) Involvement of tumor acidification in brain cancer pathophysiology. Front. Physiol. 4:316. doi: 10.3389/fphys.2013.00316

This article was submitted to Membrane Physiology and Membrane Biophysics, a section of the journal Frontiers in Physiology.

Copyright (c) 2013 Honasoge and Sontheimer. This is an open-access article distributed under the terms of the Creative Commons Attribution License (CC BY). The use, distribution or reproduction in other forums is permitted, provided the original author(s) or licensor are credited and that the original publication in this journal is cited, in accordance with accepted academic practice. No use, distribution or reproduction is permitted which does not comply with these terms. 